Article

\title{
Crop Parameters for Modeling Sugarcane under Rainfed Conditions in Mexico
}

\author{
Alma Delia Baez-Gonzalez ${ }^{1, *}$, James R. Kiniry ${ }^{2}$, Manyowa N. Meki ${ }^{3}$, Jimmy Williams ${ }^{3}$, \\ Marcelino Alvarez-Cilva ${ }^{4}$, Jose L. Ramos-Gonzalez ${ }^{1}$, Agustin Magallanes-Estala 5 \\ and Gonzalo Zapata-Buenfil ${ }^{6}$ \\ 1 Campo Experimental Pabellon, Instituto Nacional de Investigaciones Forestales, \\ Agricolas y Pecuarias (INIFAP), km 32.5 Carr, Aguascalientes-Zacatecas, Pabellon de Arteaga 20660, \\ Aguascalientes, Mexico; ramos.jose@inifap.gob.mx \\ 2 USDA, Agricultural Research Service, Grassland Soil and Water Research Laboratory, 808 E. Blackland Rd., \\ Temple, TX 76502, USA; jim.kiniry@ars.usda.gov \\ 3 AgriLife Research, Blackland Research and Extension Center, 720 E. Blackland Rd., Temple, TX 76502, USA; \\ nmeki@brc.tamus.edu (M.N.M.); jwilliams@brc.tamus.edu (J.W.) \\ 4 Campo Experimental Tecoman, Instituto Nacional de Investigaciones Forestales, Agricolas y Pecuarias, \\ km. 35, Carr, Colima-Manzanillo, Tecoman 28930, Colima, Mexico; alvarez.marcelino@inifap.gob.mx \\ 5 Campo Experimental Rio Bravo, Instituto Nacional de Investigaciones Forestales, Agricolas y Pecuarias, \\ km 61 Carr, Matamoros-Reynosa, Rio Bravo 88900, Tamaulipas, Mexico; magallanes.agustin@inifap.gob.mx \\ 6 Campo Experimental Chetumal, INIFAP, km 25.2 Carr. Chetumal-Bacalar, Ejido Juan Sarabia, \\ Municipio Othon P. Blanco 77900, Quintana Roo, Mexico; zapata.gonzalo@inifap.gob.mx \\ * Correspondence: baez.alma@inifap.gob.mx; Tel.: +52-55-387-187-00 (ext. 82503)
}

Received: 21 May 2017; Accepted: 27 July 2017; Published: 31 July 2017

\begin{abstract}
Crop models with well-tested parameters may help improve sugarcane productivity for food and biofuel generation, especially in rainfed areas where studies are scarce. This study aimed to calibrate crop parameters for the sugarcane cultivar CP 72-2086, an early-maturing cultivar widely grown in Mexico and other countries, and evaluate their adequacy in simulating sugarcane in a diverse range of rainfed conditions. For the calibration and evaluation of parameters, the ALMANAC model was used with climate, soil, management, and yield for two growing seasons from 30 farms in three regions (Northeastern Mexico, Gulf of Mexico, and Pacific Mexico). Statistical analyses were made using regression analysis and mean squared deviation and its three components, i.e., the squared bias, the lack of correlation weighted by the standard deviations, and the squared difference between standard deviations. Model simulations with a light extinction coefficient $(k)$ of 0.69 , maximum leaf area index of 7.5, leaf area index decline rate of 0.3 , optimal and minimum temperature for plant growth of $32{ }^{\circ} \mathrm{C}$ and $11{ }^{\circ} \mathrm{C}$, respectively, potential heat units of 6000 to 7400 degree days (base $11^{\circ} \mathrm{C}$ ), harvest index of 0.9 ; maximum crop height of $4.0 \mathrm{~m}$, and root depth of $2.0 \mathrm{~m}$ showed highest accuracy and captured best the magnitude of yield fluctuations with a root mean squared deviation of $7.8 \mathrm{Mg} \mathrm{ha}^{-1}$. The parameters were found to be reasonable to use in simulating sugarcane in diverse regions under rainfed conditions. Using a dynamic value of $k$ (varying during the growing season) deserves further study as it may help improve crop model precision.
\end{abstract}

Keywords: parameterization; model calibration; bioenergy crop; yield energy value

\section{Introduction}

Sugarcane (Saccharum spp.) is an important perennial crop planted in tropical and subtropical regions of the world [1,2]. One of the world's main carbohydrate sources [3], it also provides an efficient system for the conversion of photosynthate into different forms of energy [4], making it a viable source of renewable energy for transportation, electricity [1], and future technologies in biorefineries [2]. 
Thus far, the sugarcane crop is considered to have the best potential for the production of ethanol to replace fossil fuels as it shows the highest energy ratio (energy delivered per energy spent) among the biofuels [5]. Its use is expected to help mitigate the harmful effects of the petroleum-based energy system [2]. The growing pressure to increase productivity of sugarcane [4] for food production [3] and biofuel generation $[1,6]$ has resulted in a worldwide increase in sugarcane area from 23.7 million ha in 2010 to 27.1 million ha in 2014 [6,7] and a greater interest in researching sugarcane and its industrial exploitation [2]. This expansion of sugarcane cultivation, which, in some cases is on marginal lands and vulnerable to the potential impacts of climate change, presents farmers with multiple challenges, especially in countries like Mexico and Brazil, where the sugarcane industry has both social and economic impact, being the source of livelihood for many rural families [8,9].

Crop models are helpful tools in improving sugarcane productivity as they aid in the synthesis and application of knowledge and in yield forecasting [10]. Field-scale models, such as ALMANAC [11], EPIC [12], CANEGRO [3,13], and APSIM [3,14], as well as regional-scale ones, such as Agro-IBIS [15] and LPJmL [16], have been applied to energy crops under a wide range of environments. These models differ in the degree of parameterization needed and in their ability to simulate different cultivars and different stress conditions [8,17]. These complexities can be a hindrance to the application of crop models for sugarcane, possibly because of the lack of understanding of their capabilities and limitations and also because of the difficulties in using them. Another problem seems to be the general lack of model credibility [8]. For crop simulations to be reliable, high-quality field data is required for model development, and more effort is needed in the parameterization and validation of models $[10,18]$. Some of the physiological development and growth parameters that appear in model functions vary among sugarcane cultivars and therefore need to be estimated from data in order to predict growth and yield [8]. Region-specific calibrations of models are also essential [10].

Well-tested parameters are required for the development of robust crop models for reliable yield predictions [19]. Unfortunately, recent literature holds little information on parameter estimation for crop models [20]. Hence, there continues to be uncertainty regarding the allocation of parameters to sugarcane species, ecotype, and cultivar categories [21]. Parameters related to photosynthesis are particularly important to sugarcane simulation as biomass production is dependent on the amount of photosynthetically active radiation (PAR) intercepted by the crop canopy [21-23]. The light extinction coefficient $(k)$, a key parameter in sugarcane yield simulation, describes the efficiency of light interception for the canopy $[4,24-26]$. Studies have been done $[24,27]$ to compare the relationship of different $k$ values and yield of sugarcane cultivars. However, there is insufficient information on the cultivar chosen for this study, CP 72-2086, which is widely grown in Mexico and other countries. Modeling studies of sugarcane under rainfed conditions are particularly scarce. Hence, this study calibrated crop parameters for the sugarcane cultivar CP 72-2086 under rainfed conditions using the ALMANAC model and evaluated their adequacy in simulating sugarcane in a diverse range of rainfed conditions in Mexico.

\section{Materials and Methods}

\subsection{The ALMANAC Model}

This study used the ALMANAC (Agricultural Land Management Alternatives with Numerical Assessment Criteria) model, which has simulated the productivity of crops such as maize (Zea mays L.), sorghum (Sorghum bicolor L. Moench), dry bean (Phaseolus vulgaris L.) [19,28,29], rice (Oryza sativa L.), wheat (Triticum aestivum L.), and sunflower (Helianthus annuus L.) [11,30], as well as native grasses and improved pastures [31]. The model has been successfully applied to biomass simulation of bioenergy crops such as switchgrass (Panicum virgatum L.) [32-35] and sugarcane [36]. It has also been used in studies for forecasting climatic change impact on native grasses [37].

The ALMANAC model was developed for use in field management; several individual fields may be simulated to comprise a whole farm up to about 100 ha. Model input consists of weather 
(daily maximum and minimum temperatures, rainfall, and solar radiation), soils and management data. In cases where weather data or portions of weather data are missing from available databases, realistic values can be generated within the model itself [38].

The model runs on a daily time step and contains the following detailed functions to simulate growth: light interception, competition for water and nutrients among plants, biomass production, and biomass partitioning [39]. Light interception is simulated by Beer's Law and considers total leaf area and height of the canopy [39]. The water and nutrient balance subroutines are from the Erosion Productivity Impact Calculator (EPIC) model [40]. Radiation interception and radiation use efficiency (RUE) are the drivers of plant growth or biomass accumulation, which are in turn a function of the LAI and $k$ for FIPAR, as described by Monsi and Saeki's (1953) Beer's Law. RUE is a function of the vapor pressure deficit and atmospheric $\mathrm{CO}_{2}$ [41,42], while LAI evolution is simulated with a daily heat unit system that correlates plant growth with temperature. Detailed information on the main processes simulated by ALMANAC, including the equations and requisite input parameters, is provided by Kiniry [38].

The ALMANAC model can be used to compare management systems and their effects on yields, nitrogen, phosphorus, carbon, pesticides, and sediment. Among the management components that can be changed are irrigation scheduling, crop rotations, and tillage operations.

\subsection{Study Area}

Mexico produces sugarcane in 15 states grouped into six regions with a total area of 780,254 ha [43]. The study was conducted in sugarcane mill regions or "ingenios" in three Mexican states that are important in terms of total sugarcane area and production [44]: San Luis Potosí State (Northeastern Mexico), Jalisco State (Pacific Mexico), and Oaxaca State (Gulf of Mexico) (Figure 1).

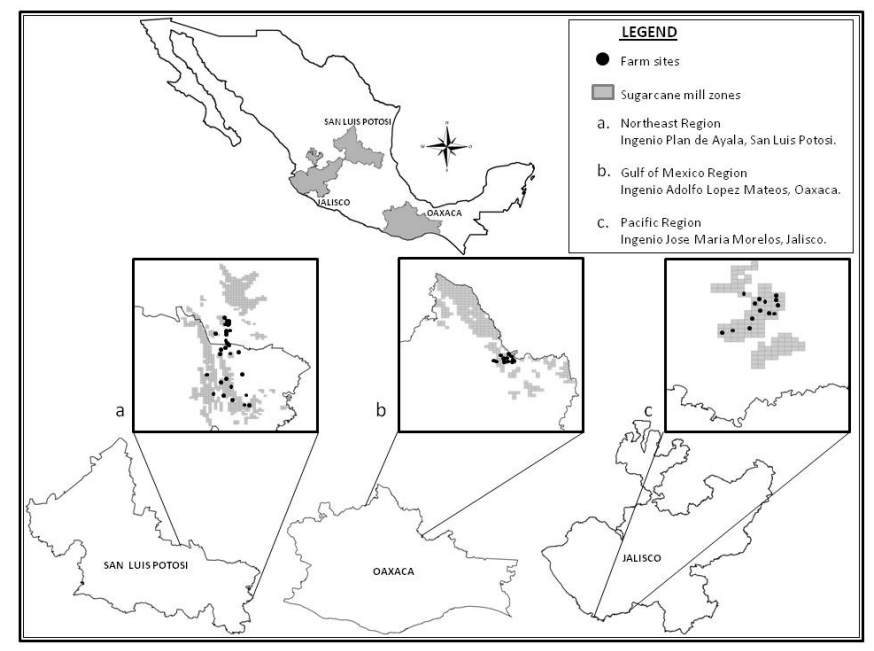

Figure 1. Thirty farm sites in three sugarcane regions of Mexico used to calibrate and validate crop parameters of an early-maturing sugarcane cultivar (CP 72-2086) under dryland conditions.

The three areas are all classified as tropical humid (Group A climate) [45], with average annual temperature of more than $18{ }^{\circ} \mathrm{C}$. However, they vary in terms of precipitation. Oaxaca (Am climate type) has precipitation of more than $2700 \mathrm{~mm}$, but at least one month has less than $60 \mathrm{~mm}$ [46]. On the other hand, Jalisco (Aw2 and Aw1 climates) has annual precipitation ranging from 483 to $1203 \mathrm{~mm}$ [46], and San Luis Potosi (Aw2 climate) has a mean annual precipitation of $1372 \mathrm{~mm}$ [47]; the dry period for both is during winter. These three areas also vary in soils. Descriptions of the soils, climate, and location of the farm sites are found in Table 1, while data on planting dates and other crop management information are in Table 2. 
Table 1. Location, soil, and climate characteristics of 30 farm sites used for the calibration and validation of crop parameters for the sugarcane cultivar CP $72-2086$ in dryland sugarcane areas in Mexico.

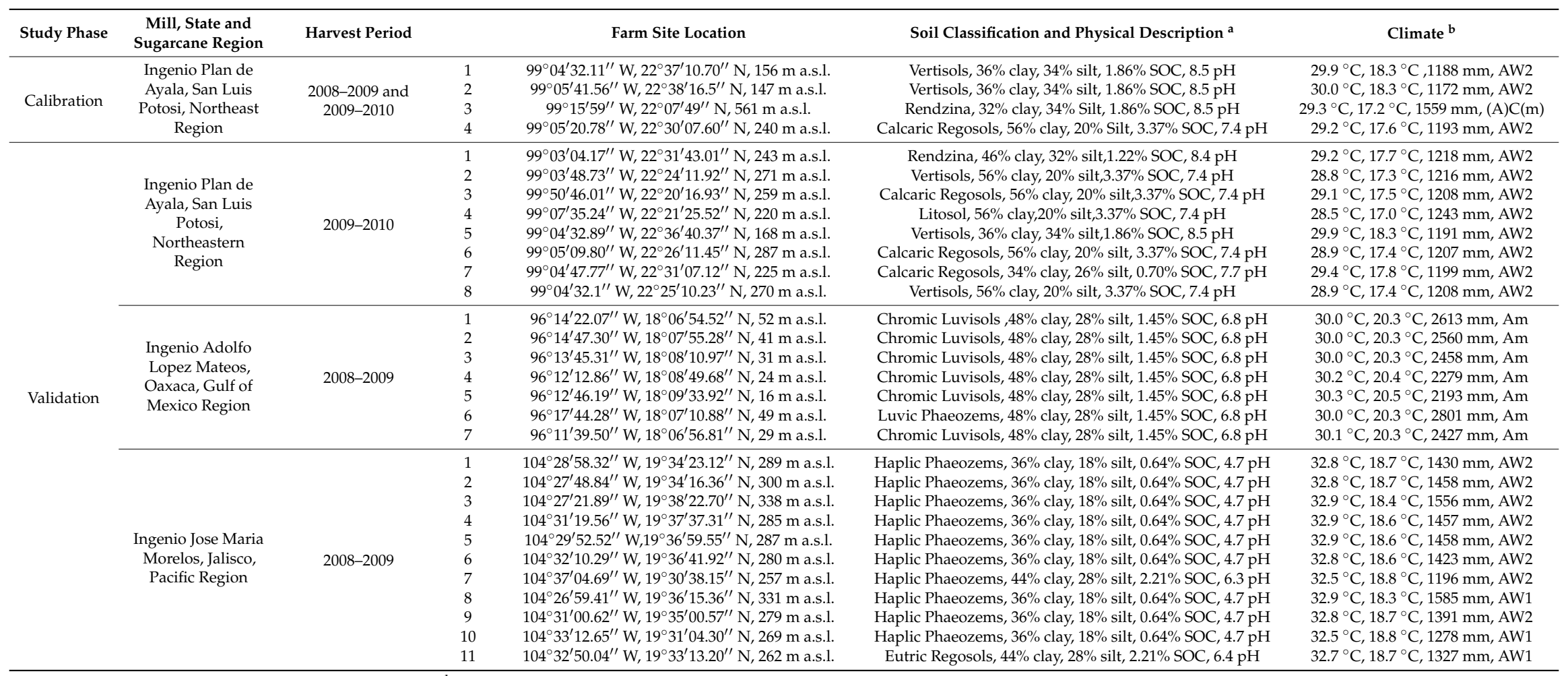

${ }^{a}$ Soil units described by FAO-UNESCO-ISRIC. ${ }^{\text {b }}$ Respectively: mean maximum and minimum temperature, mean annual rainfall, Koppën classification modified by Garcia [45]. 
Table 2. Management practices in three Mexican sugarcane regions with CP 72-2086 cultivar grown under dry land conditions (Harvest periods 2008-2009, 2009-2010).

\begin{tabular}{|c|c|c|c|}
\hline Management Practice & $\begin{array}{l}\text { Ingenio Plan de Ayala, San Luis } \\
\text { Potosi }^{\dagger} \text {. Northeastern Mexico }\end{array}$ & $\begin{array}{c}\text { Ingenio Adolfo Lopez Mateos, Oaxaca }{ }^{\dagger} . \\
\text { Gulf of Mexico }\end{array}$ & Ingenio Jose Maria Morelos, Jalisco ${ }^{\ddagger}$. Pacific Mexico \\
\hline Land Preparation & $\begin{array}{l}\text { Subsoil: February, April or May } \\
\text { First ripping: April } \\
\text { Second ripping and fallow: May } \\
\text { Herbicide application: June }\end{array}$ & $\begin{array}{l}\text { Subsoil: October-November } \\
\text { Ripping: October-November } \\
\text { Fallow: October-November } \\
\text { Herbicide application: October-November }\end{array}$ & $\begin{array}{l}\text { Subsoil: October, November and December } \\
\text { Ripping ( } 3 \text { times): October-November } \\
\text { Fallow: October-December } \\
\text { Herbicide application: June-July }\end{array}$ \\
\hline Planting period & September-November & October-December & October-December \\
\hline Plant density & $6-8 \mathrm{Mg}$ of seed billets/ha & $10 \mathrm{Mg}$ of seed billets/ha & $10-12 \mathrm{Mg}$ of seed billets/ha \\
\hline Planting method & Manual in inter-row furrows of $1.3 \mathrm{~m}$ & Manual in inter-row furrows of $1.2 \mathrm{~m}$ & Manual in inter-row furrows of $1.4 \mathrm{~m}$ \\
\hline Fertilization & $\begin{array}{l}\text { First application: } 100-50-100 \\
\text { Second application: } 138-00-00 \\
\text { Applied manually in moist soil }\end{array}$ & $\begin{array}{l}\text { Application: } 102-102-102 \\
\text { Applied manually in moist soil }\end{array}$ & $\begin{array}{c}\text { First application: } 96-96-96 \text { or } 120-60-160 \text { organic compost }\left(2 \mathrm{Mg} \mathrm{ha}^{-1}\right) \\
\text { Second application: } 92-00-00 \\
\text { Applied manually in moist soil }\end{array}$ \\
\hline Harvesting & December-April & November-January & December-January \\
\hline Other practices & Weed and pest control & Weed and pest control & Weed and pest control \\
\hline
\end{tabular}

Source of information: ${ }^{\dagger}$ Farmer interviews and on-site surveys. ${ }^{\ddagger}$ Alvarez-Cilva (unpublished data). 
The majority of producers in the studied areas are "ejidatarios" (shareholders in common lands). The rest are small farm owners and tenants [46]. Government loans and subsidies are made available to farmers to enable them to adopt recommended management practices for the sugarcane mill regions.

\subsection{Sugarcane Crop-Management Databases}

The sugarcane crop-management information used in this study (Table 2) was derived from three databases. The San Luis Potosi and Oaxaca databases consist of crop information for two growing seasons (2008-2009 and 2009-2010) obtained through interviews of sugarcane growers in the mill regions of Ingenio Plan de Ayala (San Luis Potosi State) and Ingenio Adolfo Lopez Mateos (Oaxaca State). The crop-management information (Table 2) from planting to harvest for the two growing seasons include the following: land preparation, planting period, planting density (quantity of seed billets; sections of stems that are planted), planting method, distance between furrows, sugarcane variety, application of bud-sprouting promoters, fertilization (period, dosage, type of fertilizer), pest control (type of insecticide, dosage, number of applications, time of application), weed control (type of weed, control method, type of herbicide, dosage, period of application), disease control, date of harvesting, and yield production (previous and current growing season).

The Jalisco database holds the following information obtained from sugarcane mill reports of Ingenio Jose Maria Morelos for the growing season 2008-2009: sugarcane variety, total harvested area, yield production, date of harvest, fertilization date, soil type, crop age, crop maturity, type of harvest (manual or machinery), irrigated or rainfed condition, farm site identification, type of land tenancy, sugarcane farmer organization, owners name and locality, and sugarcane inspector ID. The following additional field information was from Alvarez-Cilva (unpublished) of INIFAP (Instituto Nacional de Investigaciones Forestales, Agricolas y Pecuarias): land preparation, planting period, planting density (quantity of seeds), planting method, distance between furrows, sugarcane variety, pest control (type of insecticide and dosage), and weed control (type of weed, control method, type of herbicide, dosage).

Four farm sites from the San Luis Potosi database were used for calibration. Eight additional sites from this database were used for validation, along with seven and 11 sites from the databases of Oaxaca and Jalisco, respectively.

\subsection{Climate and Soil Databases}

The climate information used in the study (Table 1) was obtained from a climate database containing monthly "normal means" of the following parameters, derived from weather stations of the National Meteorological Service of Mexico: monthly mean maximum and minimum air temperature $\left({ }^{\circ} \mathrm{C}\right)$, monthly mean standard deviation of daily maximum and minimum temperatures $\left({ }^{\circ} \mathrm{C}\right)$, monthly mean precipitation $(\mathrm{mm})$, monthly standard deviation of daily precipitation $(\mathrm{mm})$, monthly skew coefficient for daily precipitation, monthly probability of wet day after dry day, monthly probability of wet day after wet day, and average number days of rain per month (days).

The weather generator in the ALMANAC model was used to create the daily weather data needed to run the model. This model component generates daily information on the occurrence and amount of precipitation, maximum and minimum temperatures, and total solar radiation by using Fourier coefficients and parameters that govern these weather variables [48]. It offers a convenient and adequate method of obtaining the numerous long sequences of weather data that are required for models such as EPIC and ALMANAC [48,49]. A full description of the weather generator is given in Sharpley and Williams [50]. Figure 2 shows the maximum temperature, minimum temperature and precipitation generated by the model versus the historical data recorded at the two weather stations used during the calibration process. The historical and generated data for each of the weather stations used during the validation process of the model are shown in Appendix A. The weather stations were within or close to (average distance of $33 \mathrm{~km}$ for San Luis Potosi, $23 \mathrm{~km}$ for Jalisco and $50 \mathrm{~km}$ for Oaxaca) the sugarcane mill supply areas under study (Figure 3). 

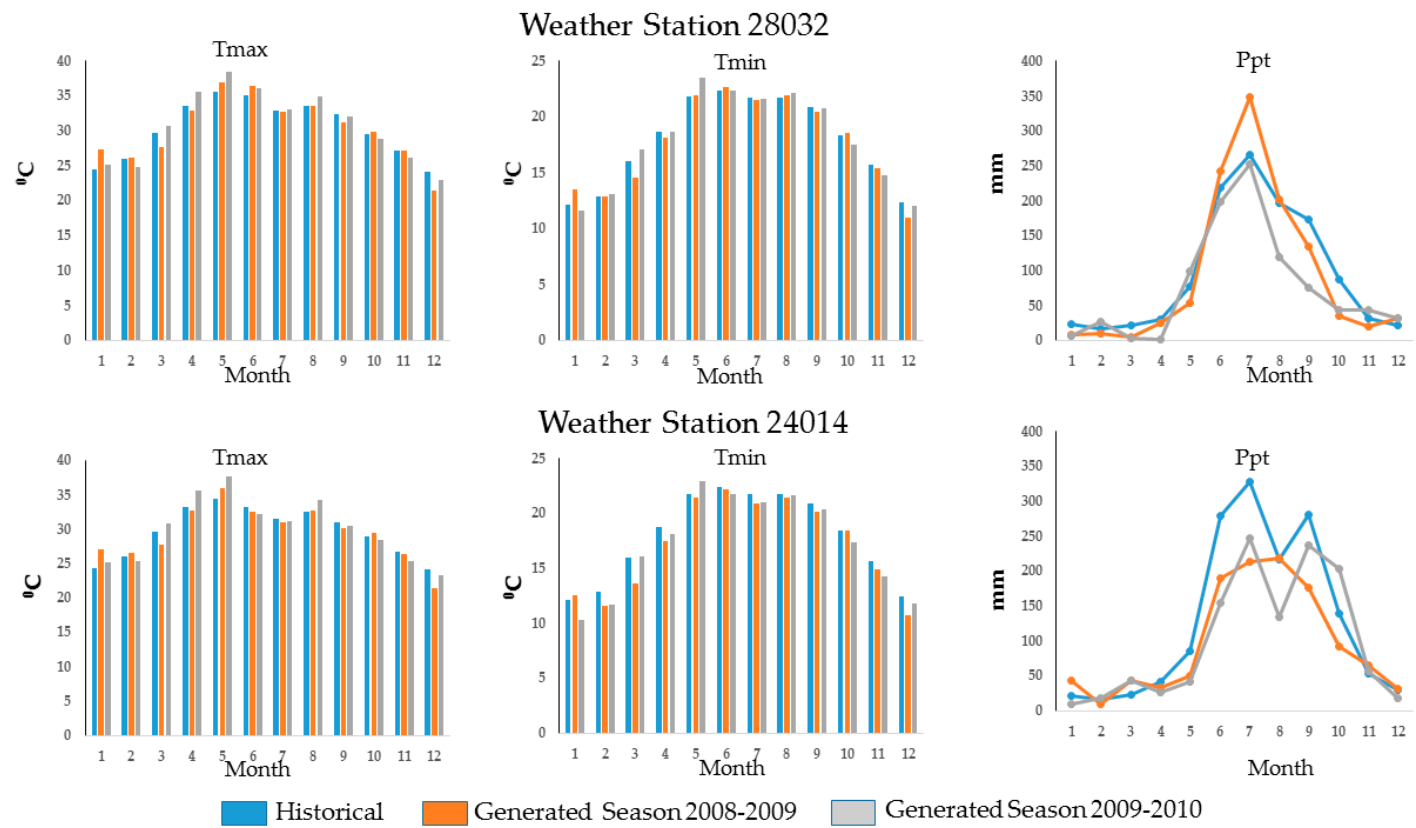

Figure 2. Maximum and minimum temperature and precipitation generated by the ALMANAC model for the growing seasons 2008-2009 and 2009-2010, and the historical data recorded in two weather stations used in the calibration process.

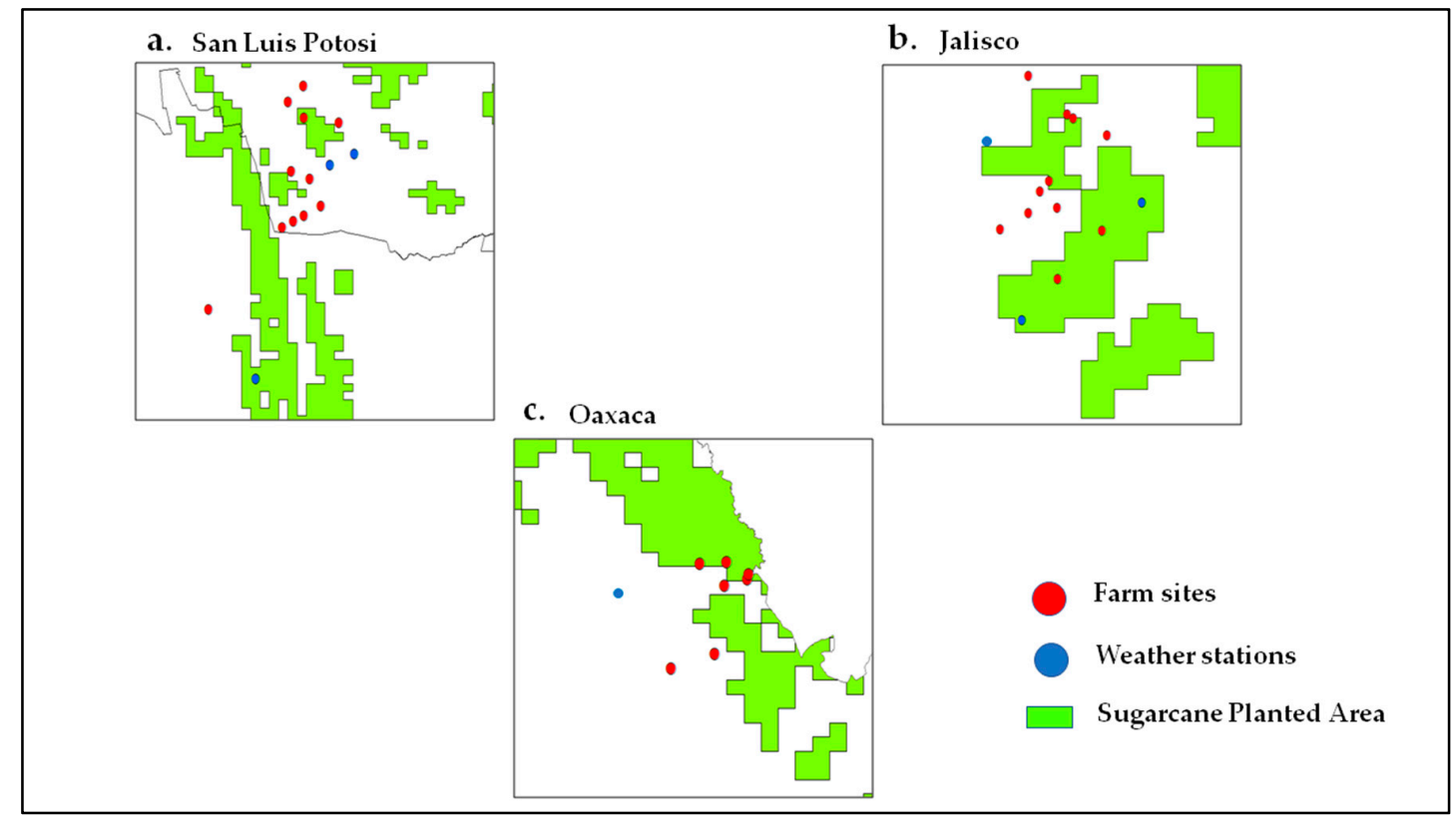

Figure 3. Farm sites and selected weather stations within or close to the sugarcane mill supply areas of (a) Ingenio Plan de Ayala, San Luis Potosi (Northeastern Mexico), (b) Ingenio Jose Maria Morelos, Jalisco (Pacific Mexico), and (c) Ingenio Adolfo Lopez Mateos, Oaxaca, Gulf of Mexico.

The soil database contains the following information from the National Program of the Sugarcane Agroindustry (Programa Nacional de la Agroindustria de la Caña de Azucar, PRONAC) [51]: soil depth $(\mathrm{m})$, soil texture (sand, clay, and silt concentrations), bulk density $\left(\mathrm{t} \mathrm{m}^{-3}\right), \mathrm{pH}$, cation exchange capacity $(\mathrm{cmol} / \mathrm{kg})$, and organic carbon concentration (\%).

Latitude and longitude were indicated for each weather and soil information. The data used in the study were chosen considering proximity to farm sites (Figure 3). 


\subsection{Sugarcane Cultivar}

The study used the cultivar CP 72-2086 because it is one of the three main sugarcane cultivars in Mexico [52] and is widely grown in other parts of the world. It is grown in Pakistan [53], Zimbabwe [54], the United States [55], Venezuela [56], Costa Rica [57,58], Guatemala [59], Nicaragua [60], and other countries. It was once the most widely grown cultivar in Florida (USA) [61]. In Oaxaca State (Mexico), where many rural households depend on sugarcane for their livelihood, this cultivar and Mex 69-290 cover $94 \%$ of the area [9]. Schuenneman et al. [60] provides a detailed description of the CP 72-2086 cultivar.

Higher yields at early and late harvest have been reported for CP 72-2086 [62]. In Mexico, it is considered an early-maturing variety [52], with a mean potential yield of $110-120 \mathrm{Mg} \mathrm{ha}^{-1}$ under rainfed conditions and $135-140 \mathrm{Mg} \mathrm{ha}^{-1}$ under irrigated conditions in the sub-humid tropics. With the lack of early-maturing Mexican sugarcane varieties [63], CP 72-2086 has become the preferred cultivar of many Mexican farmers because of its high yield and early maturation. This cultivar makes it possible to avoid crop damage due to harsh winter conditions in some regions and to provide cane to the mills at the start of the harvest season.

\subsection{Calibration of Crop Parameters}

The ALMANAC model simulates critical growth processes and the impacts of various field-level management alternatives on the soil and water environment and on crop yields. The model was designed to simulate a wide range of plant species in a general way that can be easily transferred to new environments and applied to different plant species [28]. The requisite input parameters for growth and development can be easily derived from field experiments.

Calibration of crop parameters, the process of finding parameters that provide the best correlation between a model and the reality it is simulating [64], is part of model calibration aimed at finding the best fit for a certain regional environment of interest [65]. Calibration refers to refining the initial selection of parameters used to run the model by comparing the model results with observed data [66]. This process is useful in deriving parameters that are not available for agricultural areas or crops [67-69].

The crop parameters considered in this study were leaf area index (LAI), light extinction coefficient (k), RUE (biomass-energy ratio, $\mathrm{g} \mathrm{MJ}^{-1} \mathrm{~m}^{-2}$ ), optimum and minimum temperature for plant growth, fraction of the season when LAI starts to decline, leaf area decline rate index, first and second points on LAI curve (i.e., two points on the curve of optimal non-stress leaf area development), maximum crop height $(\mathrm{m})$, maximum root depth $(\mathrm{m})$, potential heat units $\left({ }^{\circ} \mathrm{C}\right)$ (base temperature $11^{\circ} \mathrm{C}$, optimum temperature $32{ }^{\circ} \mathrm{C}$ ), dry matter decline rate index, and harvest index. The LAI curve defines how LAI develops (in the absence of water stress) as a function of the fraction of heat units to maturity. After anthesis, the rate of decline in LAI also differs within the model as a function of degree days. Crop height is similarly simulated as a fraction of the degree days to anthesis. To define the range of values for these crop parameters, we first obtained the values for sugarcane within the database of the ALMANAC model, which are similar to those in the EPIC model [40]. The values from the model, which were for a one-year sugarcane crop growth cycle, were then compared with those reported by Meki et al. [36] for a two-year cycle sugarcane. They were also compared with values reported by Inman-Bamber [13] for a cultivar with a variable cycle of one to two years and by Singels and van den Berg [21] for a wide range of ecotypes and cultivars. A new template with possible suitable parameter values for sugarcane cultivar CP 72-2086 was then created.

The field information (management, production, soil type, and climate) of four rainfed farm sites (average size 7 ha) in the Ingenio Plan de Ayala mill region in San Luis Potosi (Tables 1 and 2) was used to run the model and calibrate each crop parameter. The sites were selected at random from all the sites in the database that were planted to CP 72-2086. Production was simulated for two harvest periods (2008-2009 and 2009-2010) and compared against the measured yield data reported for each plot for each harvest period. The potential heat units (PHUs, base and optimum temperatures of 11 
and $32^{\circ} \mathrm{C}$ ) value was defined in the model according to the management schedule while considering information from farmers. The crop parameters were adjusted iteratively, i.e., the model was run numerous times, the simulated aboveground dry biomass yields were compared with actual data, and crop parameter values were adjusted until there was a good match between predicted and measured dry matter yield values.

The modeling process provides a better understanding of the complex interaction between leaves and their environment [70]. In this study, the importance of light extinction coefficient $(k)$ in determining canopy photosynthesis [25] became evident during the initial parameterization phase, presenting a strong influence on the simulation of sugarcane. Hence, we also made a sensitivity analysis of $k$. The model was run again 40 times (four farm sites $\times$ five $k$ values $\times$ two growing seasons); in each run, the value of $k$ was changed while the values of all other parameters were kept constant. The $k$ values that were used were $0.53,0.56,0.65,0.67$, and 0.69 because they had been previously reported in other studies for sugarcane cultivars $[8,13,21,36,40,71]$.

\subsection{Validation of Crop Parameters in Three Regions}

The validation of the performance of a model is usually done by running the model under the same conditions used for its calibration, but with a different set of data. In this study, we used another set of farm sites from the database of San Luis Potosi (the region considered in the calibration) for the validation. In addition, we also evaluated model performance and the stability of the parameters in rainfed areas with diverse climate and soil conditions. For this, we used rainfed farm sites from San Luis Potosi and also from sugarcane mill regions in Jalisco State (Pacific Mexico) and Oaxaca (Gulf of Mexico). A total of 26 randomly selected rainfed farms were used in the evaluation of the crop parameters to establish their usefulness in simulating CP 72-2086 sugarcane under rainfed conditions: eight farms (average size 7 ha) in San Luis Potosi (Northeastern Mexico), 11 farms (average size 5 ha) in Jalisco (Pacific Region), and seven farms (average size 8 ha) in Oaxaca (Gulf of Mexico Region) (Figure 1, Tables 1 and 2).

The model was run 104 times ( 26 farm sites $\times$ four $k$ values) using the different $k$ values that performed well during the sensitivity analysis and all the other crop parameters resulting from the calibration process. In each run, only the $k$ value was modified, and all other crop parameters were kept constant. All the previously selected $k$ values were considered, except 0.56 . The criterion for the selection of $k$ values to be included in the validation process was that they present the lowest value in at least one of the three components of MSD. In the case of $k 0.56$, its values in all the MSD components were higher than those of the other four $k$ values $(0.53,0.65,0.67$, and 0.69$)$.

\subsection{Statistical Analysis}

A regression analysis was made to simulate sugarcane dry matter yield as a function of measured dry matter yield and to determine the significance of the regression model. However, combining an $R^{2}$ analysis with other statistical analyses - in this case, the three components of MSD-made it possible to measure model efficiency from different angles. For further comparison of the model performance, the three components of mean squared deviation $\left(\mathrm{MSD}=\mathrm{RMSD}^{2}\right.$ ) were calculated, i.e., the squared bias (SB), the squared difference between standard deviations (SDSD), and the lack of correlation weighted by the standard deviations (LCS) [72]. SDSD and LCS were calculated using the following equations:

$$
\begin{gathered}
\mathrm{SDSD}=\left(\mathrm{SD}_{\mathrm{s}}-\mathrm{SD}_{\mathrm{m}}\right)^{2} \\
\mathrm{LCS}=2 \mathrm{SD}_{\mathrm{s}} \mathrm{SD}_{\mathrm{m}}(1-r)
\end{gathered}
$$

where $\mathrm{SD}_{\mathrm{s}}$ and $\mathrm{SD}_{\mathrm{m}}$ are the standard deviation of the simulation and the measurement respectively; $r$ is the correlation coefficient.

The SB represents the bias of the simulation from the measurement. The LCS shows the lack of positive correlation weighted by the standard deviations. The SDSD is the difference in the magnitude 
of fluctuation between the simulation and measurement [72]. As mentioned by Kobayashi and Salam [72] and Bellocchi et al. [73], the MSD test is better suited to the $x-y$ comparison and easier to interpret than regression. The correlation-regression approach tends to focus on the contrast with a lower correlation and regression line far from the equality line, while the analysis of MSD clearly identifies the simulation vs. measurements contrast with larger deviation than others [72]. In this study, we decided to use both approaches.

\section{Results}

\subsection{Sugarcane Crop Parameters}

Fourteen crop parameters based on the values for sugarcane contained in the ALMANAC database and those reported by Meki et al. [36], Inman-Bamber [13], and Singels and van den Berg [21] were calibrated for the one-year cycle sugarcane cultivar CP 72-2086 under rainfed conditions. Table 3 shows the parameter values that had the best fit with the cultivar under study. The model using the following crop parameters showed highest accuracy and captured best the magnitude of yield fluctuations: maximum leaf area index of 7.5 , leaf area index decline rate of 0.3 , optimal and minimum temperature for plant growth of $32{ }^{\circ} \mathrm{C}$ and $11{ }^{\circ} \mathrm{C}$, respectively, potential heat units 6000 to 7400 degree days base $11^{\circ} \mathrm{C}$, harvest index 0.9 , maximum crop height of $4.0 \mathrm{~m}$, root depth of $2.0 \mathrm{~m}$, and a $k$ of 0.69 . Other parameters are in Table 3.

Table 3. Crop parameters calibrated for an early maturing, one-year growth cycle sugarcane cultivar (CP 72-2086) under dryland conditions in Mexico. The biomass-energy ratio is equivalent to radiation use efficiency.

\begin{tabular}{ccc}
\hline Parameter Name & Units & Value \\
\hline Biomass-energy ratio & $\mathrm{g} \mathrm{MJ}^{-1} \mathrm{~m}^{-2}$ & 3.4 \\
Optimal temperature & ${ }^{\circ} \mathrm{C}$ & 32 \\
Minimum temperature & ${ }^{\circ} \mathrm{C}$ & 11 \\
Maximum Leaf Area Index & & 7.5 \\
Leaf area decline rate index & & 0.9 \\
Fraction of season when LAI starts to decline & & 0.3 \\
Light extinction coefficient for Beer's Law & & 0.69 \\
First point on optimal LAI curve & & $25 ; 25^{*}$ \\
Second point on optimal LAI curve & & $90 ; 95^{*}$ \\
Potential heat units & ${ }^{\circ} \mathrm{C}$ & $6000-7400$ \\
Maximum crop height & $\mathrm{m}$ & 4 \\
Maximum root depth & $\mathrm{m}$ & 2 \\
Dry matter decline rate index & & 0.1 \\
Harvest index & & 0.9 \\
\hline
\end{tabular}

* Two points on optimal (nonstress) leaf area development curve. Numbers before semicolon are \% of growing season. Numbers after semicolon are fractions of maximum potential leaf area index (LAI).

The resulting values for maximum leaf area index (7.5), leaf area decline rate index (0.30), and maximum root depth (2.0) were similar to those of Meki et al. [36]. As for the biomass-energy ratio, which represents the potential (unstressed) growth rate (including roots), the value of $3.4 \mathrm{~g} \mathrm{MJ}^{-1} \mathrm{~m}^{-2}$ [36] proved suitable for use with CP 72-2086. For the dry matter decline rate index, which indicates reduction in the efficiency of conversion of intercepted photosynthetically active radiation to biomass due to production of high energy products like seeds and/or translocation of $\mathrm{N}$ from leaves to seeds [40], the default value of 0.1 in the ALMANAC model proved to be adequate in this study. The minimum temperature value of $11^{\circ} \mathrm{C}$ is close to the $12{ }^{\circ} \mathrm{C}$ value reported by Marin and Jones [8] for sugarcane in Brazil, while the value of $32{ }^{\circ} \mathrm{C}$ for optimal temperature is similar to that reported by NeTafim [74] for sugarcane. 
As for $k$, the initial analysis showed that the use of any value of $k$ resulted in an $\mathrm{R}^{2}$ of 0.94 or 0.95 (Figure 4). Further analysis using MSD components (Figure 5) showed that the $k$ value of 0.65 had a lower value of squared bias. However, with $k$ values 0.67 and 0.69 , the model showed a greater ability to simulate the magnitude and pattern of fluctuations in production (lower values in squared difference between standard deviation and lack of correlation weighted by the standard deviation). These values were evaluated to determine the best $k$ value for large-scale simulations of sugarcane under rainfed conditions. The values of root mean squared deviation (RMSD) were 5.9, 5.1, 4.5, 3.9 and $3.8 \mathrm{Mg} \mathrm{ha}^{-1}$ for $k 0.53,0.51,0.65,0.67$, and 0.69 , respectively (Table 4 ).
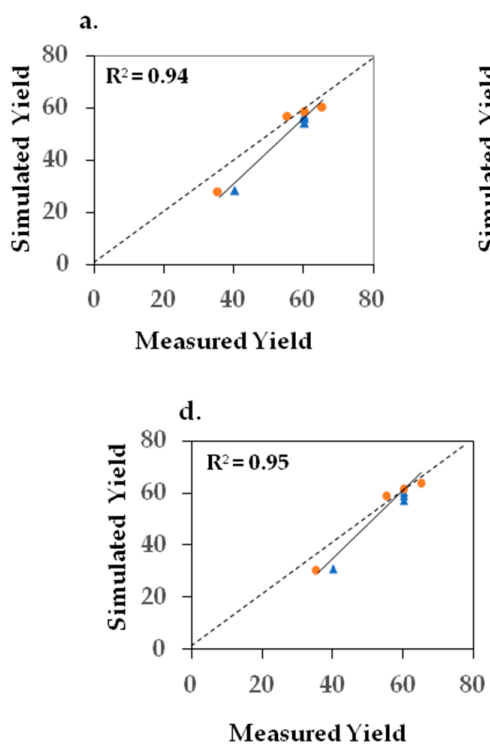

b.
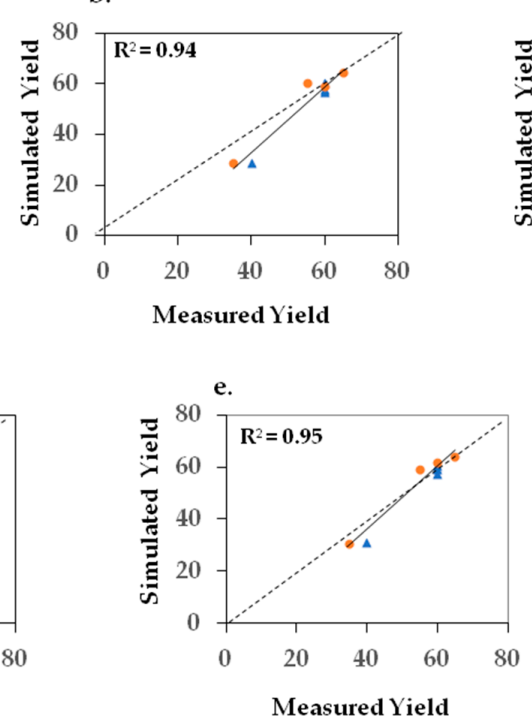

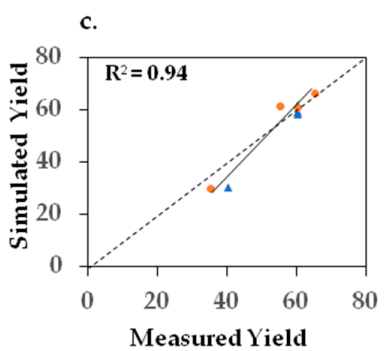

$\triangle$ Growing season 2008/09

Growing season $2009 / 10$

Figure 4. Coefficient of determination $\left(\mathrm{R}^{2}\right)$ of measured and simulated sugarcane yield $\left(\mathrm{Mg} \mathrm{ha}^{-1}\right)$ of CP 72-2086 cultivar under rainfed conditions in four farm sites during two growing seasons (2008-2009 and 2009-2010) in Mexico, using light extinction coefficient (k) values of (a) 0.53, (b) 0.56, (c) 0.65, (d) 0.67 , and (e) 0.69 with other derived parameters. The solid lines are the fitted regressions and the dashed lines are the 1:1 lines.

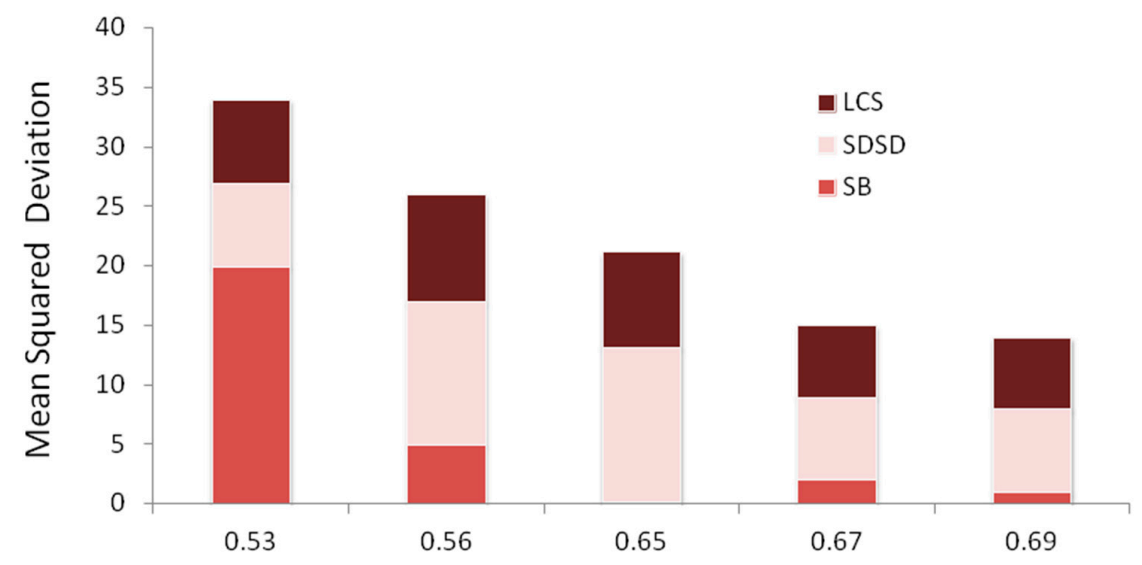

Light extinction coefficient $(k)$

Figure 5. Comparison of the mean squared deviation (MSD) and its components, lack of correlation weighted by the standard deviations (LCS), squared difference between standard deviations (SDSD), and squared bias (SB) for the calibration of the CP 72-2086 sugarcane cultivar using different light extinction coefficient $(k)$ values with other derived parameters. 
Table 4. Measured and simulated sugarcane yield in Northeastern Mexico using light extinction coefficient $(k)$ and other crop parameters during the calibration process.

\begin{tabular}{|c|c|c|c|c|c|c|c|}
\hline \multirow{2}{*}{ Harvest Period } & \multirow{2}{*}{ Farm Site } & \multirow{2}{*}{ Measured Yield $\left(\mathrm{Mg} \mathrm{ha}^{-1}\right)$} & \multicolumn{5}{|c|}{ Simulated Yield $\left(\mathrm{Mg} \mathrm{ha}^{-1}\right)$ with Crop Parameters } \\
\hline & & & $k 0.53$ & $k 0.56$ & $k 0.65$ & $k 0.67$ & $k 0.69$ \\
\hline \multirow{4}{*}{ 2008-2009 } & 1 & 60 & 54.0 & 57.7 & 59.7 & 57.3 & 57.7 \\
\hline & 2 & 60 & 57.0 & 60.3 & 62.4 & 60.3 & 60.7 \\
\hline & 3 & 40 & 28.2 & 28.9 & 30.7 & 31.1 & 31.5 \\
\hline & 4 & 60 & 55.9 & 56.7 & 58.8 & 59.2 & 59.5 \\
\hline \multirow{6}{*}{ 2009-2010 } & 1 & 55 & 56.8 & 60.3 & 61.8 & 58.9 & 59.2 \\
\hline & 2 & 65 & 60.6 & 64.5 & 66.6 & 64.0 & 64.4 \\
\hline & 3 & 35 & 27.9 & 28.6 & 30.4 & 30.8 & 31.1 \\
\hline & 4 & 60 & 58.5 & 59.2 & 61.3 & 61.7 & 62.0 \\
\hline & Mean & 54.4 & 49.9 & 52.0 & 54.0 & 52.9 & 53.3 \\
\hline & RMSD & & 5.9 & 5.1 & 4.5 & 3.9 & 3.8 \\
\hline
\end{tabular}

* Maximum leaf area index of 7.5; leaf area index decline rate of 0.3; optimal and minimum temperature for plant growth of $32{ }^{\circ} \mathrm{C}$ and $11^{\circ} \mathrm{C}$, respectively; potential heat units of 6000 to 7400 degree days (base $11^{\circ} \mathrm{C}$ ); harvest index of 0.9 ; maximum crop height of $4.0 \mathrm{~m}$ and root depth of $2.0 \mathrm{~m}$.

\subsection{Validation of Parameters in Three Regions}

To measure their stability and suitability for simulations at a wider scale, the crop parameters were evaluated in the region used for parameterization and in two other regions with diverse climates and soils. All sites had been planted to CP 72-2086 under rainfed conditions. In addition to the $k$ value of 0.69 , the $k$ values of 0.53 and 0.65 were included in the evaluation because they presented the lowest value in at least one of three components of MSD (Figure 5); the $0.67 k$ value was also evaluated because it showed an LCS value similar to $0.69 k$, i.e., both $k$ values simulated with the same precision the magnitude of fluctuation of yields (Figure 5).

The results of the evaluation showed that in the case of the Ingenio Plan de Ayala mill region in San Luis Potosi (Northeastern Region), the use of $k 0.65$ with other derived parameters resulted in lower value of squared bias ( $\mathrm{SB}=1.0)$. This $k$ value is the default value for sugarcane in models such as EPIC [40] and ALMANAC when the $k$ value is not known; it has also been reported for maize [75]. On the other hand, the magnitude of fluctuations in production was simulated in the same way (SDSD $=4$ ) with 0.69 and any other value of $k$, possibly because the magnitude of fluctuations of production was not very wide in the selected sites in this mill region (yields were within a range of 55 to $65 \mathrm{Mg} \mathrm{ha}^{-1}$ with a mean of $58.5 \mathrm{Mg} \mathrm{ha}^{-1}$ ). However, the model using $k 0.69$ resulted in the lowest overall deviation $(\mathrm{MSD}=15)$ with an RMSD of $3.9 \mathrm{Mg} \mathrm{ha}^{-1}$ (Table 5).

Table 5. Root mean squared deviation (RMSD) of simulated sugarcane yield in three regions of Mexico using light extinction coefficient $(k)$ and other crop parameters during the validation process.

\begin{tabular}{|c|c|c|c|c|c|}
\hline \multirow[t]{2}{*}{ Sugarcane Region } & \multirow{2}{*}{ Number of Farm Sites } & \multicolumn{4}{|c|}{$\begin{array}{l}\text { RMSD }\left(\mathrm{Mg} \mathrm{ha}^{-1}\right) \text { of Yield } \\
\text { Simulation with Crop Parameters * }\end{array}$} \\
\hline & & $k 0.53$ & $k 0.65$ & $k 0.67$ & $k 0.69$ \\
\hline Northeastern Mexico & 8 & 4.0 & 3.9 & 4.0 & 3.9 \\
\hline Gulf of Mexico & 7 & 11.4 & 10.1 & 9.8 & 9.4 \\
\hline Pacific Mexico & 11 & 11.4 & 9.1 & 8.9 & 8.7 \\
\hline Three regions combined & 26 & 9.7 & 8.2 & 8.0 & 7.8 \\
\hline
\end{tabular}

* Maximum leaf area index of 7.5; leaf area index decline rate of 0.3; optimal and minimum temperature for plant growth of $32{ }^{\circ} \mathrm{C}$ and $11{ }^{\circ} \mathrm{C}$, respectively; potential heat units of 6000 to 7400 degree days (base $11^{\circ} \mathrm{C}$ ); harvest index of 0.9 ; maximum crop height of $4.0 \mathrm{~m}$ and root depth of $2.0 \mathrm{~m}$.

For the Ingenio Adolfo Lopez Mateos mill region in Oaxaca (Gulf of Mexico Region), the use of $0.69 k$ with the other parameters resulted in highest accuracy $(\mathrm{SB}=15.0)$, best simulation of the pattern and magnitude of fluctuations (SDSD $=33.0$ and LCS $=41.0$ ), and the lowest overall deviation 
$(\mathrm{MSD}=89.0)$ and with an RMSD of $9.4 \mathrm{Mg} \mathrm{ha}^{-1}$ (Table 5). In this mill region, the production range of the selected sites was 47 to $70 \mathrm{Mg} \mathrm{ha}^{-1}$ with a mean of $60.8 \mathrm{Mg} \mathrm{ha}^{-1}$. The model considering the value of $k 0.69$ can adequately capture this variability in production and may be used with other parameters in future simulations of sugarcane in this region.

In the case of the Ingenio Jose Maria Morelos mill region in Jalisco (Pacific Region), the $k$ value of 0.69 used with the other parameters also showed the best accuracy, the lowest overall deviation value $(\mathrm{SB}=6.0$ and $\mathrm{MSD}=75.4)$, and the lowest $\mathrm{RMSD}$ value $\left(8.7 \mathrm{Mg} \mathrm{ha}^{-1}\right)$ (Table 5). The range of measured yield was 50 to $80 \mathrm{Mg} \mathrm{ha}^{-1}$ with a mean of $67.3 \pm 11.2 \mathrm{Mg} \mathrm{ha}^{-1}$.

In the analysis considering the combined data of all three regions to see the feasibility of using a single value of $k$ for all the sugarcane regions, it was observed that the model using $k$ values of 0.67 and 0.69 had the best accuracy ( $S B=7.0$ ) and captured the magnitude of fluctuations (SDSD = 15.0), while with $0.69 k$, it showed better precision in simulating the pattern of fluctuations (LCS = 39.0). The lowest overall deviation (MSD $=61.0$ ) was for $k 0.69$ with an RMSD of $7.8 \mathrm{Mg} \mathrm{ha}^{-1}$ (Table 5); this $k$ value is thus considered the best value to use in the large-scale simulation of sugarcane cultivar CP 72-2986 under rainfed conditions. This value is close to the 0.68 value cited by Marin and Jones [8] and the 0.699 value reported by Zhou et al. [76] for SP83-2847 and ZN7 sugarcane, respectively.

As mentioned earlier, $k 0.65$ is already included in the crop parameter database of the models EPIC and ALMANAC for use with several crops, such as sorghum, wheat and maize. Based on the results of this study, it is considered a reasonable value to use when the $k$ value for a sugarcane variety is unknown.

Process-oriented plant models like ALMANAC or EPIC currently consider only one value of $k$ for the simulation of the entire crop cycle. Considering a dynamic value of $k$ (i.e., varying during the growing season) may help improve model accuracy. An example of this was reported by Inman-Bamber [13], who, while running a model for sugarcane, changed the value of $k$ from 0.58 to 0.86 when more than 15 emerged leaves were predicted for primary shoots. Zhou et al. [76] reported an increase in $k$ in four sugarcanes cultivars with increasing crop age. Varying the $k$ value according to the development and growth stage of the simulated crop may lead to a more precise simulation of the crop development process and therefore to greater accuracy in the yield simulation. Additional studies are needed in this regard.

\section{Conclusions}

The crop parameters that were calibrated and validated under a range of climatic, soil, and crop management conditions (Table 3) proved adequate for simulations of rainfed CP 72-2086 sugarcane. The model simulations had low RMSD ranging from 3.9 to $9.4 \mathrm{Mg} \mathrm{ha}^{-1}$ or $<10 \mathrm{Mg} \mathrm{ha}^{-1}$ in all the three regions that had varied total annual precipitation ranging from 1100 to $2800 \mathrm{~mm}$. They also demonstrated the versatility of the cultivar CP 72-2086 in adapting to both tropical and subtropical regions as seen in the amplitude of parameters, such as optimal temperature of $32{ }^{\circ} \mathrm{C}$ and minimum temperature of $11^{\circ} \mathrm{C}$ for crop growth, and potential heat units ranging from 6000 to 7400 .

The light extinction coefficient $(k)$ proved to be an important parameter in the yield simulation of sugarcane in this study. The value of $k 0.69$ was found suitable for use with the other derived parameters in simulating the cultivar CP 72-2086 under diverse rainfed conditions. The value of $k 0.65$ is considered a reasonable value to use when the $k$ value for a sugarcane variety is unknown. Further study is needed to determine if the adjustment of the $k$ value during the simulation of sugarcane crop growth and development may help increase the accuracy of models, such as ALMANAC.

Acknowledgments: The authors thank the participating Mexican farmers and the sugarcane mills of Ingenio Jose Maria Morelos in Jalisco and Ingenio Plan de Ayala in San Luis Potosi for providing data. They also thank the anonymous reviewers for their valuable suggestions and Elvira Aranda Tabobo for her help in editing the manuscript. This paper is an output of the sabbatical project of Alma Delia Baez-Gonzalez made possible by the Grassland, Soil, and Water Research Laboratory (GSWRL) of the USDA-ARS, the Instituto Nacional de Investigaciones Forestales, Agricolas y Pecuarias (INIFAP), and the Consejo Nacional de Ciencia y Tecnologia (CONACyT). 
Author Contributions: Alma Delia Baez-Gonzalez designed the study and prepared the initial manuscript; James R. Kiniry and Jimmy R. Williams contributed to the modeling aspect; Alma Delia Baez-Gonzalez, James R. Kiniry, and Manyowa N. Meki analyzed the results and participated in writing the final manuscript; Marcelino Alvarez Cilva, Jose Luis Ramos Gonzalez, Agustin Magallanes Estala, and Gonzalo Zapata Buenfil contributed to data acquisition and to the discussion. All authors read and approved the final manuscript.

Conflicts of Interest: The authors declare no conflict of interest.

\section{Appendix A}

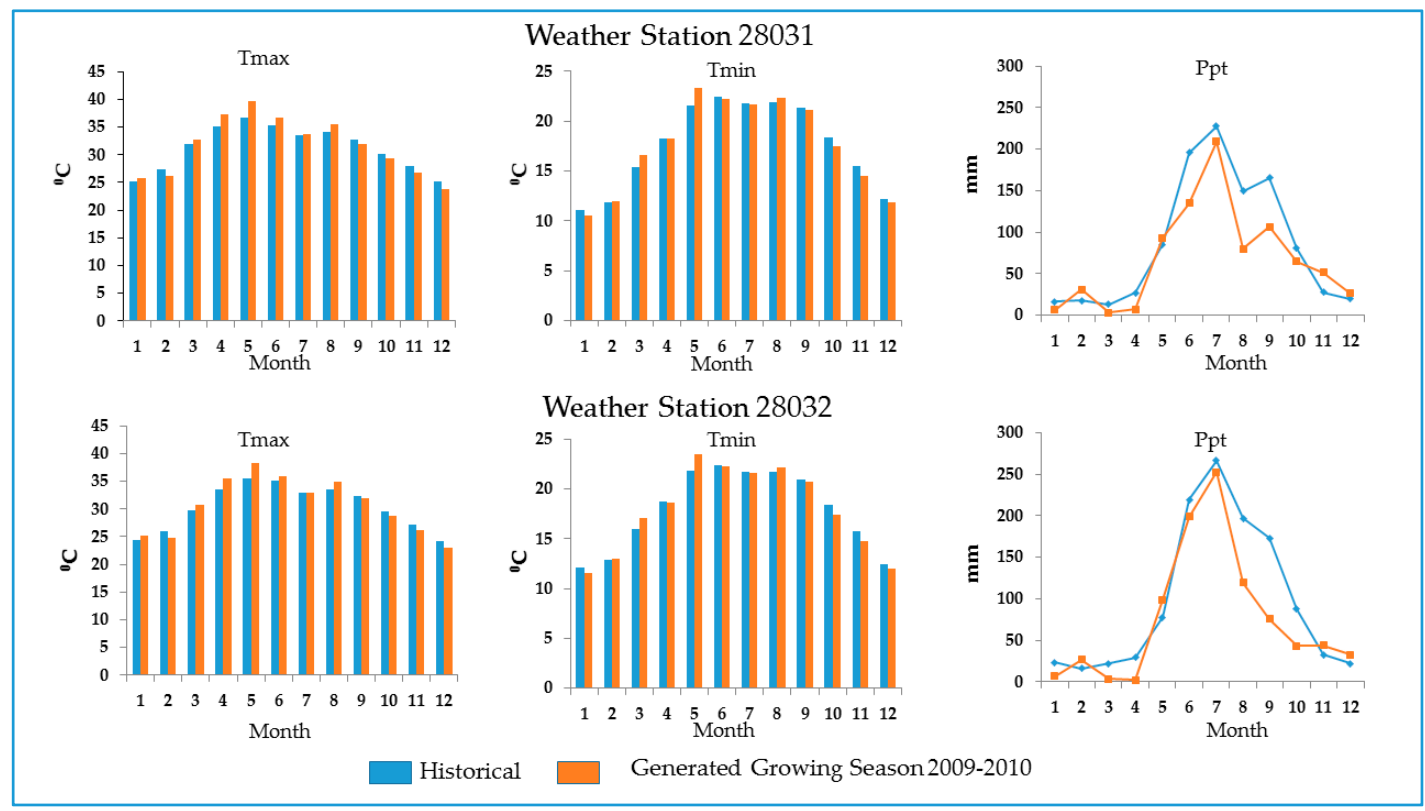

(a)

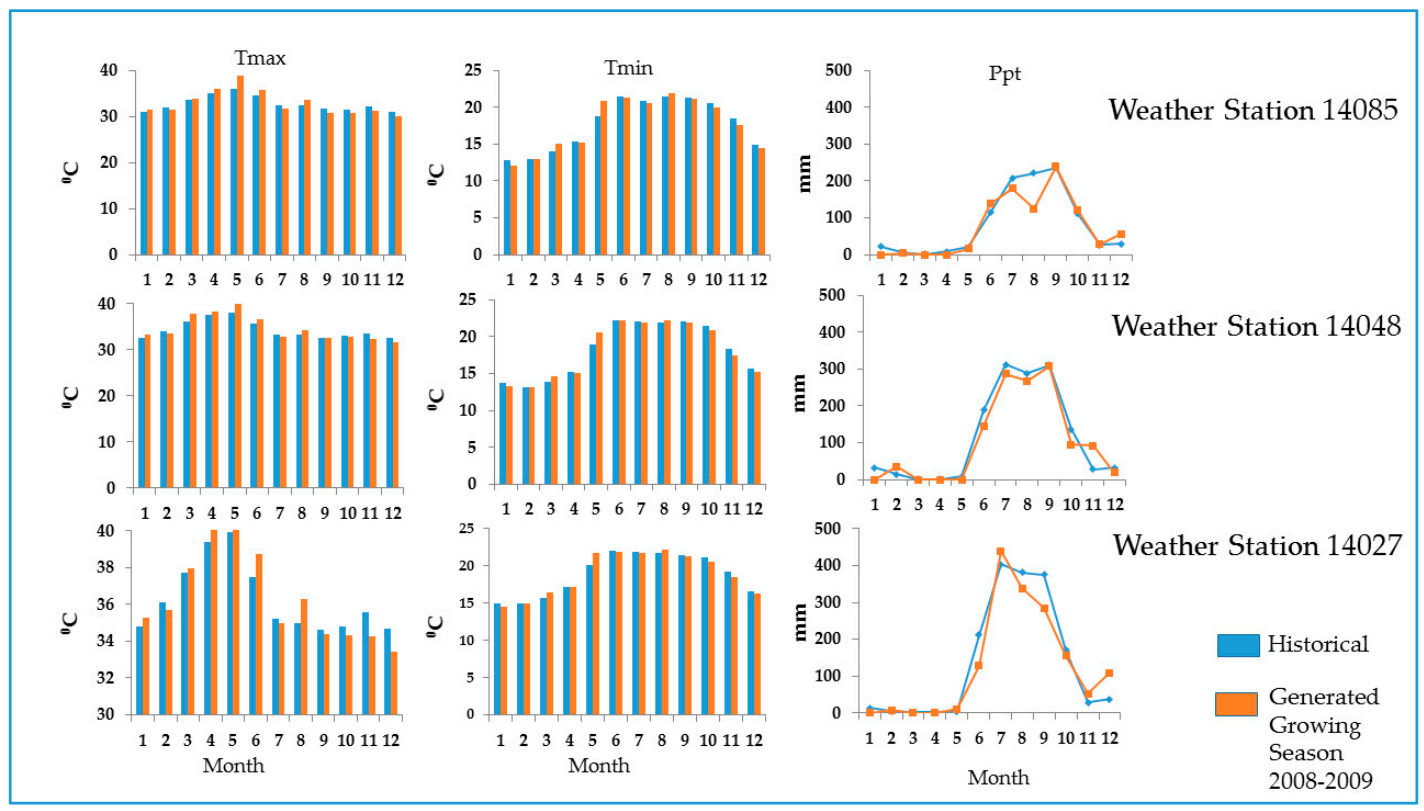

(b)

Figure A1. Cont. 


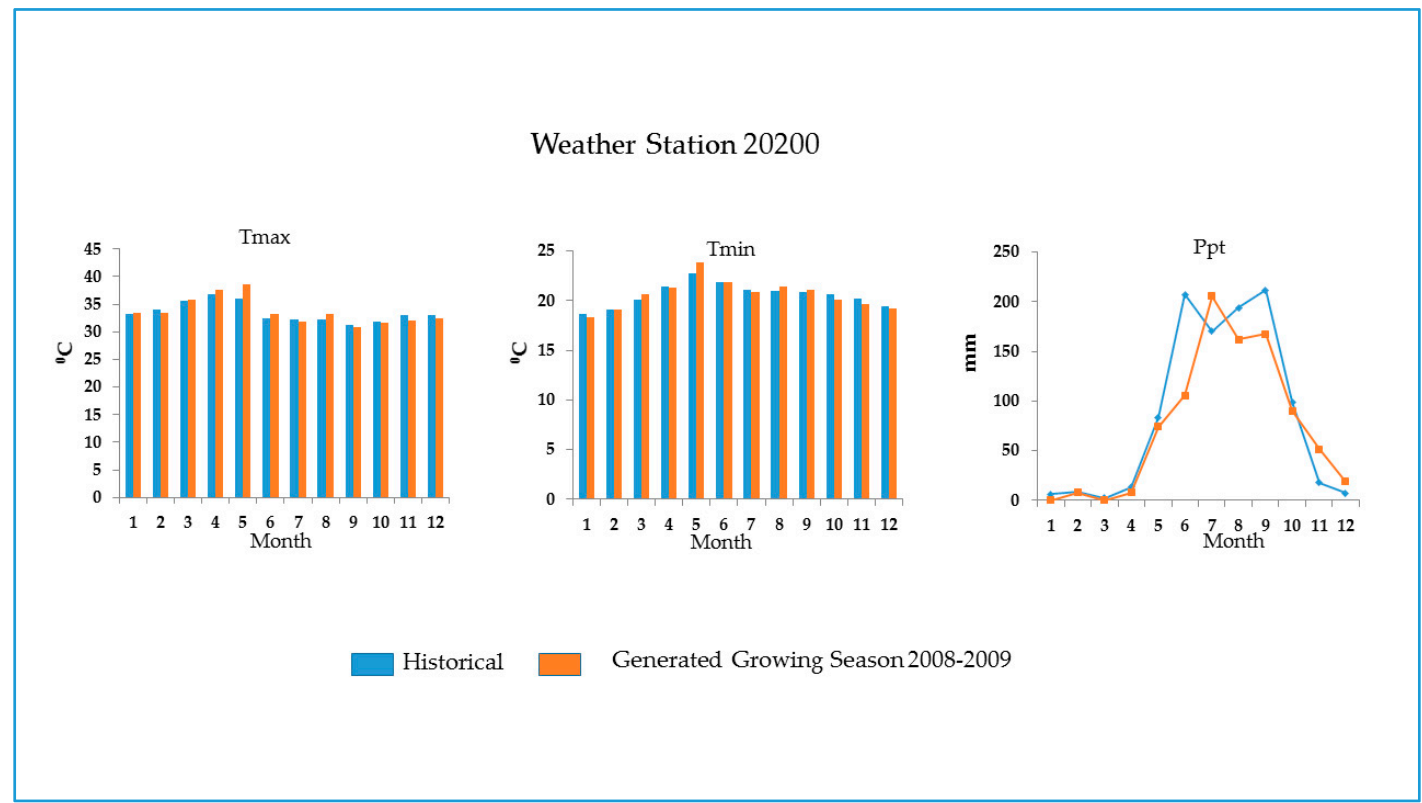

(c)

Figure A1. Historical and ALMANAC-generated weather data used for validation of sugarcane parameters in (a) Ingenio Plan de Ayala, San Luis Potosi (Northeastern Mexico), (b) Ingenio Jose Maria Morelos, Jalisco (Pacific Mexico), and (c) Ingenio Adolfo Lopez Mateos, Oaxaca, Gulf of Mexico.

\section{References}

1. Lin, H.; Chen, J.; Pei, Z.; Zhang, S.; Hu, X. Monitoring sugarcane growth using ENVISAT ASAR data. Geoscience and Remote Sensing. IEEE Trans. Geosci. Remote Sens. 2009, 47, 2572-2580. [CrossRef]

2. Matsuoka, S.; Stolf, R. Sugarcane tillering and ratooning: Key factors for a profitable cropping. In Sugarcane: Production, Cultivation and Uses; Goncalves, J., Correia, K., Eds.; Nova Science Publishers Inc.: Hauppauge, NY, USA, 2012; pp. 137-157.

3. Marin, F.R.; Thorburn, P.J.; Nassif, D.S.; Costa, L.G. Sugarcane model intercomparison: Structural differences and uncertainties under current and potential future climates. Environ. Model. Softw. 2015, 72, 372-386. [CrossRef]

4. Ascencio, J.; Lazo, J.V. The Shade Avoidance Syndrome under the Sugarcane Crop; Intech Open Access Publisher: Rijeka, Croatia, 2012.

5. Valade, A.; Ciais, P.; Vuichard, N.; Viovy, N.; Caubel, A.; Huth, N.; Marin, F.; Martiné, J.-F. Modeling sugarcane yield with a process-based model from site to continental scale: Uncertainties arising from model structure and parameter values. Geosci. Model Dev. 2014, 7, 1225-1245. [CrossRef]

6. Valade, A.; Vuichard, N.; Ciais, P.; Ruget, F.; Viovy, N.; Gabrielle, B.; Huth, N.; Martiné, J.F. ORCHIDEE-STICS, a process-based model of sugarcane biomass production: Calibration of model parameters governing phenology. GCB Bioenergy 2014, 6, 606-620. [CrossRef]

7. Food and Agriculture Organization of the United Nations. FAO Statistics. Available online: http://www. fao.org/faostate (accessed on 12 July 2016).

8. Marin, F.R.; Jones, J.W. Process-based simple model for simulating sugarcane growth and production. Sci. Agric. 2014, 7, 11-16. [CrossRef]

9. Bravo-Mosqueda, E.; Baez-Gonzalez, A.D.; Tinoco-Alfaro, C.A.; Mariles-Flores, V.; Osuna-Ceja, E. Yield-gap analysis of a homogenous area and zonification of a sugarcane mill region in Oaxaca, Mexico. J. Crop Improv. 2014, 28, 772-794. [CrossRef]

10. Andrade, A.S.; Santos, P.M.; Pezzopane, J.R.M.; de Araujo, L.C.; Pedreira, B.C.; Pedreira, C.G.S.; Marin, F.R.; Lara, M.A.S. Simulating tropical forage growth and biomass accumulation: An overview of model development and application. Grass Forage Sci. 2015, 71, 54-65. [CrossRef] 
11. Kiniry, J.R.; Williams, J.R.; Gassman, P.W.; Debaeke, P. A General, Process-Oriented Model for Two Competing Plant Species. Trans. ASAE 1992, 3, 801-810.

12. Williams, J.R.; Jones, C.A.; Dyke, P.T. The EPIC Model and Its Application. In Proceedings of the International Symposium on Minimum Data Sets for Agrotechnology Transfer, Andhra Pradeshe, India, 21-26 March 1983.

13. Inman-Bamber, N. A growth model for sugar-cane based on a simple carbon balance and the CERES-Maize water balance. S. Afr. J. Plant Soil 1991, 8, 93-99. [CrossRef]

14. Keating, B.A.; Robertson, M.J.; Muchow, R.C.; Huth, N.I. Modelling sugarcane production systems I. Development and performance of the sugarcane module. Field Crops Res. 1999, 61, 253-271. [CrossRef]

15. Kucharik, C.J. Evaluation of a process-based agro-ecosystem model (Agro-IBIS) across the US corn belt: Simulations of the interannual variability in maize yield. Earth Interact. 2003, 7, 1-33. [CrossRef]

16. Bondea, U.A.; Smith, P.C.; Zaehle, S.; Schaphof, S.; Lucht, W.; Cramer, W.; Gerten, D.; Lotze-Campen, H.; Muller, C.; Reichstein, M.; et al. Modelling the role of agriculture for the 20th century global terrestrial carbon balance. Glob. Chang. Biol. 2007, 13, 679-706. [CrossRef]

17. O'Leary, G.J. A review of three sugarcane simulation models with respect to their prediction of sucrose yield. Field Crops Res. 2000, 68, 97-111. [CrossRef]

18. Surendran, N.S.; Kang, S.; Zhang, X.; Miguez, F.E.; Izaurralde, R.C.; Post, W.M.; Dietze, M.C.; Lynd, L.R.; Wullschleger, S.D. Bioenergy crop models: Descriptions, data requirements, and future challenges. GCB Bioenergy 2012, 4, 620-633. [CrossRef]

19. Baez-Gonzalez, A.D.; Kiniry, J.R.; Padilla, R.J.S.; Medina, G.G.; Ramos, G.J.L.; Osuna, C.E.S. Parametrization of ALMANAC Crop Simulation Model for Non-Irrigated Dry Bean in Semi-Arid Temperate Areas in Mexico. Interciencia 2015, 40, 185-189.

20. Ahuja, L.R.; Ma, L. A synthesis of current parameterization approaches and needs for further improvements. In Methods of Introducing System Models into Agricultural Research; Ahuja, L.R., Ma, L., Eds.; American Society of Agronomy Inc.: Madison, WI, USA; Crop Science Society of America Inc.: Madison, WI, USA; Soil Science Society of America Inc.: Madison, WI, USA, 2011; pp. 427-440.

21. Singels, M.J.; van den Berg, M. DSSAT v4.5-Canegro Sugarcane Plan Module. Scientific Documentation. International Consortium for Sugarcane Modelling (ICSM). Available online: http://sasri.sasa.org.za/misc/ icsm.html (accessed on 14 November 2015).

22. Ma, L.; Ahuja, L.R.; Saseendran, S.A.; Malone, R.W.; Green, T.R.; Nolan, B.T.; Bartling, P.N.S.; Flerchinger, G.N.; Boote, K.J.; Hoogenboom, G.A. Protocol for parameterization and calibration of RZWQM2 in field research. In Methods of Introducing System Models into Agricultural Research; Ahuja, L.R., Ma, L., Eds.; American Society of Agronomy Inc.: Madison, WI, USA; Crop Science Society of America Inc.: Madison, WI, USA; Soil Science Society of America, Inc.: Madison, WI, USA, 2011; pp. 1-64.

23. Guo, L.P.; Kang, H.J.; Ouyang, Z.; Zhuang, W.; Yu, Q. Photosynthetic parameters estimations by considering interactive effects of light, temperature and $\mathrm{CO}_{2}$ concentration. Int. J. Plant Prod. 2015, 9, 321-345.

24. Shimabuku, M. Studies on the yield of sugarcane varieties with particular reference to the efficiency structure and light extinction coefficient of communities of some sugarcane varieties. Jpn. J. Trop. Agric 1976, 19, 151-155.

25. Hikosaka, K.; Hirose, T. Leaf angle as a strategy for light competition: Optimal and evolutionarily stable-extinction coefficient within a leaf canopy. Ecoscience 1997, 4, 501-507. [CrossRef]

26. Singels, A.; Donaldson, R.A. A Simple Model of Unstressed Sugarcane Canopy Development. Proc. S. Afr. Sugar Technol. Assoc. 2000, 74, 151-154.

27. Shimabuku, M.; Higa, K. Studies on the yield of sugarcane varieties with particular reference to the efficiency of the utilization on sunlight. Part 3. The effects of light extinction coefficient on some yield components in some sugarcane varieties. Congress of the International Society of Sugar Cane Technologists. Plant Breed. 1977, 16, 177-185.

28. Xie, Y.; Kiniry, J.R.; Nedbalek, V.; Rosenthal, W.D. Maize and sorghum simulation with CEREs-Maize, SORKAM, and ALMANAC under water-limiting conditions. Agron. J. 2001, 93, 1148-1155. [CrossRef]

29. Meki, M.N.; Snider, L.J.; Kiniry, J.R.; Raper, L.R.; Rocateli, C.A. Energy sorghum biomass harvest thresholds and tillage effects on soil organic carbon and bulk density. Ind. Crops Prod. 2013, 43, 172-182. [CrossRef]

30. Kiniry, J.R.; Jones, C.A.; O'toole, J.C.; Blanchet, R.; Cabelguenne, M.; Spanel, D.A. Radiation-use efficiency in biomass accumulation prior to grain-filling for five grain-crops species. Field Crops Res. 1989, 20, 51-64. [CrossRef] 
31. Kiniry, J.R.; Burson, B.L.; Evers, G.W.; Williams, L.R.; Sanchez, H.; Wade, C.; Featherson, J.W.; Greenwade, J. Coastal bermudagrass, bahiagrass, and native range simulation at diverse sites in Texas. Agron. J. 2007, 99, 450-461. [CrossRef]

32. Kiniry, J.R.; Lynd, L.; Greene, N.; Johnson, M.V.; Casler, M.; Laster, M.S. Biofuels and water use: Comparison of maize and switchgrass and general perspectives. In New Research on Biofuels; Wright, J.H., Evans, D.A., Eds.; Nova Science Publishers Inc.: Hauppauge, NY, USA, 2008; pp. 1-14.

33. Kiniry, J.R.; Schmer, M.R.; Vogel, K.P.; Mitchell, R.B. Switchgrass biomass simulation at diverse sites in the Northern Great Plains of the U.S. Bioenergy Res. 2008, 1, 259-264. [CrossRef]

34. Mclaughlin, B.S.; Kiniry, J.R.; Taliaferro, C.M.; De La Torre, U.D. Projecting yield and utilization potential of switch grass as an energy crop. Adv. Agron. 2006, 90, 267-297. [CrossRef]

35. Woli, P.; Paz, J.O.; Lang, D.J.; Baldwin, B.S.; Kiniry, J.R. Soil and variety effects on the energy and carbon balances of switchgrass-derived ethanol. J. Sustain. Bionergy Syst. 2012, 2, 65-74. [CrossRef]

36. Meki, M.N.; Kiniry, J.R.; Youkkhana, A.H.; Crow, S.E.; Ogashi, R.M.; Nakahata, M.H.; Tirado-Corba, L.R.; Anderson, R.G.; Osorio, J.; Jeong, J. Two-year growth cycle sugarcane crop parameters attributes and their application in modelling. Agron. J. 2015, 107, 1310-1320. [CrossRef]

37. Behrman, D.K.; Kiniry, J.R.; Winchell, M.; Juenger, T.E.; Keitt, T.H. Spatial forecasting of switchgrass productivity under current and future climate change scenarios. Ecol. Appl. 2013, 23, 73-83. [CrossRef] [PubMed]

38. Kiniry, J.R. A general crop model. In Modeling and Remote Sensing Applied to Agriculture (U.S. and Mexico); Richardson, W.C., Baez-Gonzalez, A.D., Tiscareno-Lopez, M., Eds.; USDA-ARS: Washington, DC, USA; INIFAP Ciudad de Mexico, Mexico, 2006; pp. 1-12.

39. Kiniry, J.R.; Blanchet, R.; Williams, J.R.; Texier, V.; Jones, C.A.; Cabelguenne, M. Simulating sunflower with the EPIC and ALMANAC models. Field Crops Res. 1992, 30, 403-423. [CrossRef]

40. Williams, J.R.; Jones, C.A.; Kiniry, J.R.; Spanel, D.A. The EPIC crop growth model. Trans. ASAE 1989, 32, 497-511. [CrossRef]

41. Kemanian, A.R.; Stockle, C.O.; Huggins, D.R. Variability of barley radiation-use efficiency. Crop Sci. 2004, 44, 1662-1672. [CrossRef]

42. Stockle, C.A.; Kiniry, J.R. Variability in crop radiation use efficiency associated with vapor pressure deficit. Field Crops Res. 1990, 21, 171-181. [CrossRef]

43. Official Journal of The Federation (Diario Oficial de la Federacion). Programa Nacional de la Agroindustria de la Caña de Azucar 2014-2018; Edicion Vespertina Mexico: Mexico City, Mexico, 2014. (In Spanish)

44. SIAP (Servicio De Información Agroailmentaria Y Pesquera) Cierre de la Producción Agrícola Por Cultivo 2012. Available online: http://www.siap.gob.mx/index.php?option=com_wrapper\&view=wrapper\& Itemid=350 (accessed 21 November 2015). (In Spanish)

45. Garcia, E. Modificaciones al Sistema de Clasificación Climática de Köppen, 2nd ed.; Instituto de Geografía, UNAM: Ciudad de Mexico, Mexico, 1973; p. 246.

46. Mexican Sugarcane Manual (Manual Azucarero Mexicano). Cuadragésima Séptima Edición, 47th ed.; Compañía Editora del Manual Azucarero, S.A. de C.V.: Ciudad de Mexico, Mexico, 2004. (In Spanish)

47. Magallanes, E.A.; Lopez, L.A.; Ramirez, G.R.A. Caracterizacion del Ingenio Plan de Ayala, San Luis Potosi. In Caracteristicas Climaticas y Edaficas de las Zonas de Abastecimiento de Ingenios Cañeros en Mexico. Climatic and Soil Characteristics of the Sugarcane Mill Supply Zones in Mexico; Baez-Gonzalez, A.D., Medina-Garcia, G., Ruiz-Corral, J.A., Ramos-Gonzalez, J.L., Eds.; Libro Tecnico No. 13; INIFAP-SAGARPA: Ciudad de Mexico, Mexico, 2012; pp. 269-302. (In Spanish)

48. Richardson, C.W.; Nicks, A.D. Weather generator description. In EPIC-Erosion/Productivity Impact Calculator. 1. Model Documentation; Sharpley, A.N., Williams, J.R., Eds.; Technical Bulletin No. 1768; U.S. Department of Agriculture: Washington, DC, USA, 1990; pp. 93-103.

49. Nicks, A.D.; Richardson, C.W.; Williams, J.R. Evaluation of the EPIC model generator. In EPIC—Erosion/Productivity Impact Calculator. 1. Model Documentation; Sharpley, A.N., Williams, J.R., Eds.; Technical Bulletin No. 1768; U.S. Department of Agriculture: Washington, DC, USA, 1990; pp. 105-124.

50. Sharpley, A.N.; Williams, J.R. EPIC—Erosion/Productivity Impact Calculator. 1. Model Documentation; Technical Bulletin No. 1768; U.S. Department of Agriculture: Washington, DC, USA, 1990; p. 235. 
51. PRONAC (Programa Nacional de la Agroindustria de la Caña de Azucar). Digitalizacion del Campo Cañero en Mexico para Alcanzar la Agricultura de Precision de la Caña de Azucar. Desarrollo de un Modelo Integral de Sistema de Informacion Geografica y Edafica como Fundamento de la Agricultura de Precision en la Caña de Azucar en Mexico. Formato Digital. 2009. Digital Format. Available online: http://www. intechopen.com/books/crop-plant/the-shade-avoidance-syndrome-under-the-sugarcane-crop (accessed on 16 June 2015).

52. Milanes-Ramos, N.; Ruvalcaba, V.E.; Caredo, M.B.; Barahona, P.O. Effects of Location and Time of Harvest on Yields of the Three Main Sugarcane Varieties in Mexico. Proc. Int. Soc. Sugar Cane Technol. 2010, 27, 1-10.

53. Hussnain, S.-Z.; Afghan, S.; Road, T.; Haq, M.-I.; Mughal, S.-M.; Shahazad, A.; Hussain, K.; Nawaz, K.; Pan, Y.-B.; Batool, A.; et al. First report of ratoon stunt of sugarcane caused by Leifsoni xyli subsp. xyli in Pakistan. Plant Dis. 2011, 95, 1581. [CrossRef]

54. Shoko, M.D.; Zhou, M.; Pieterse, P.J. The use of Soybean (Glycine max) as a break crop affect the cane and sugar yield of sugarcane (Saccharum officinarum) variety CP 72-2086 in Zimbabwe. World J. Agric. Sci. 2009, 5, 567-571.

55. Sinclair, T.R.; Gilbert, R.A.; Perdomo, R.E.; Shine, J.M., Jr.; Powell, G.; Montes, G. Sugarcane leaf area development under field conditions in Florida, USA. Field Crops Res. 2004, 88, 171-178. [CrossRef]

56. Rea, R.; De Souza, O.; Gonzalez, V. Caracterizacion de catorce variedades promisoras de caña de azucar en Venezuela Characterization of fourteen promising sugarcane varieties in Venezuela. Revista Cana de Azucar 1994, 12, 3-45. (In Spanish)

57. Fermin, S.J. Calidad del jugo y contenido de fibra de tres variedades de caña de azucar en un ciclo de crecimiento en Guanacaste, Costa Rica Juice quality and fiber content of three varieties of sugarcane in one growth cycle in Guanacaste, Costa Rica. Agronomia Costarriciense 1998, 22, 173-184. (In Spanish)

58. Chavarria, E.F.; Vega, S.J.; Ralda, G.; Glynn, N.C.; Comstock, J.C.; Castlebury, A. First report of orange rust of sugarcane caused by Puccinia kuehnii in Costa Rica and Nicaragua. Plant Dis. 2009, 93, 425. [CrossRef]

59. Ovalle, W.; Comstock, J.C.; Glynn, N.C.; Castlebury, L.A. First Report of Puccinia kuehnii, Causau Agent of Orange Rust of Sugarcane, in Guatemala. Plant Dis. 2008, 92, 973. [CrossRef]

60. Schuenneman, T.J.; Miller, J.D.; Gilbert, R.A.; Harrison, N.L. Sugarcane Cultivar CP 72-2086 Descriptive Fact Sheet; University of Florida Cooperative Extension Service, Institute of Food and Agricultural Sciences: Gainesville, FL, USA, 2008; SSAG115; pp. 1-4.

61. Todd, J.; Glaz, B.; Burner, D.; Kimbeng, C. Historical use of cultivars as parents in Florida and Louisiana sugarcane breeding programs. Hindawi Publishing Corporation. Int. Sch. Res. 2015, 2015, 257417. [CrossRef]

62. Miller, J.D.; Tai, P.Y.P.; Glaz, B.; Dean, J.L.; Kang, M.S. Registration of CP 72-2086 sugarcane. Crop Sci. 1984, 24, 210. [CrossRef]

63. Aguilar, N.; Debernardi, L. Efecto de la floracion en la calidad agroindustrial de la variedad de caña de azucar CP 72-2086 en Mexico. Effect of flowering on the agroindustrial quality of CP 72-2086 sugarcane in Mexico. Caña de Azucar 2004, 22, 19-37. (In Spanish)

64. Skrehota, O. Quantitative Structure-Property Relationship Modeling Algorithms, Challenges and IT Solutions. Ph.D. Thesis, Masaryk University Faculty of Informatics, Brno, Czechoslovakia, 2010.

65. Ko, J.; Piccinn, G.; Guo, W.; Steglich, E. Parameterization of EPIC crop model for simulation of cotton growth in South Texas. J. Agric. Sci. 2009, 147, 169-178. [CrossRef]

66. Ahuja, L.R.; Ma, L. Parameterization of agricultural system models: Current approaches and future needs. In Agricultural Systems Models in Field Research and Technology Transfer; Ahuja, L.R., Ma, L., Howell, T.A., Eds.; Lewis Publishers: Boca Raton, FL, USA, 2002; pp. 273-316.

67. Driessen, P.M.; Konijn, N.T. Land-Use Systems Analysis; Wageningen Agricultural University, Department of Soil Science \& Geology: Wageningen, The Netherlands, 1992; p. 230.

68. Monteiro, L.A.; Sentelhas, P.C. Potential and actual sugarcane yields in southern Brazil as a function of climate conditions and crop management. Sugar Technol. 2013, 16, 264-276. [CrossRef]

69. Odongo, V.; Onyando, J.; Mutua, B.; van Oel, P.R.; Becht, R. Sensitivity analysis and calibration of the Modified Universal Soil Loss Equation (MUSLE) for the Upper Malewa Catchment, Kenya. Int. J. Sediment Res. 2013, 28, 368-383. [CrossRef]

70. Harley, P.C.; Tenhunen, J.D. Modeling the photosynthetic response of $\mathrm{C}_{3}$ leaves to environmental factors. In Modeling Crop Photosynthesis_From Biochemistry to Canopy; CSSA special publication No. 19; American Society of Agronomy and Crop Science of America: Madison, WI, USA, 1991; pp. 17-39. 
71. Inman-Bamber, N.G.; Thompson, G.D. Models of Dry Matter Accumulation by Sugarcane. Proc. S. Afr. Sugar Technol. Assoc. 1989, 63, 212-216.

72. Kobayashi, K.; Salam, M.U. Comparing simulated and measured values using mean squared deviation and its components. Agron. J. 2000, 92, 345-352. [CrossRef]

73. Bellocchi, G.; Rivington, M.; Donatelli, M.; Matthews, K. Validation of biophysical models: Issues and methodologies. A review. Agron. Sustain. Dev. 2010, 30, 109-130. [CrossRef]

74. Netafim. Sugarcane. Available online: http://www.sugarcanecrops.com/climate/ (accessed on 15 July 2015).

75. Jones, C.A.; Kiniry, J.R. CERES-Maize Model: A Simulation Model of Maize Growth and Development; Texas A\&M University Press: College Station, TX, USA, 1986.

76. Zhou, M.M.; Singels, A.; Savage, M.J. Physiological Parameters for Modeling Differences in Canopy Development between Sugarcane Cultivars. Proc. S. Afr. Sugar Technol. Assoc. 2002, 7, 610-621.

2017 by the authors. Licensee MDPI, Basel, Switzerland. This article is an open access article distributed under the terms and conditions of the Creative Commons Attribution (CC BY) license (http:// creativecommons.org/licenses/by/4.0/). 